Acta Universitatis Nicolai Copernici • Pedagogika XLI/1/2021

Nauki Humanistyczno-Społeczne • Zeszyt 453

DOI: http://dx.doi.org/10.12775/AUNC_PED.2021.002

\title{
Urszula Wróblewska
}

Uniwersytet w Białymstoku

ORCID: 0000-0003-3585-3903

\section{WYCHOWANIE PRZEDSZKOLNE W DrugieJ RzeczypospoliteJ MIĘDZY TEORIĄ, PRAKTYKA I NIEDOCENIONYM DZIEDZICTWEM PEDAGOGICZNYM \\ Preschool Education in the Second Polish Republic Between Theory, Practice and the Underappreciated Pedagogical Heritage}

\begin{abstract}
Streszczenie
Celem artykułu naukowego pt. „Wychowanie przedszkolne w Drugiej Rzeczypospolitej. Między teorią, praktyką i niedocenionym dziedzictwem pedagogicznym" jest ukazanie początków wychowania przedszkolnego w okresie międzywojennym oraz historii rozwoju przedszkoli w Polsce. Omówiono rodzaje form opieki nad małym dzieckiem, przyczyny zakładania przedszkoli oraz teoretyczne założenia i praktyczne rozwiązania proponowane przez twórczynię wychowania przedszkolnego Marię Weryho-Radziwiłłowiczową. Zagadnienie zostało omówione w kontekście potrzeby świadomości, tradycji wychowania przedszkolnego we współczesnych trendach przedszkolnych.

Słowa kluczowe: wychowanie przedszkolne, Druga Rzeczpospolita, Maria Weryho-Radziwiłłowiczowa, historia wychowania, dziedzictwo pedagogiczne
\end{abstract}




\begin{abstract}
The aim of the scientific article: „Preschool Education in the Second Polish Republic Between Theory, Practice and Underappreciated Pedagogical Heritage", is to show the beginnings of pre-school education in the interwar period and the history of the development of kindergartens in Poland. It discusses the types of care for a small child, the reasons for the establishment of kindergartens and the theoretical assumptions and practical solutions proposed by the creator of pre-school education Maria Weryho-Radziwiłłowiczowa. The issue was discussed in the context of the need for awareness, the tradition of pre-school education in modern pre-school trends.
\end{abstract}

Ke y w ord s: preschool education, the Second Polish Republic, Maria Weryho-Radziwiłłowiczowa, history of education, pedagogical heritage

\title{
Wprowadzenie
}

Celem niniejszego artykułu jest zwrócenie uwagi Czytelnika na sce i wskazanie obszarów, które stanowią chlubną kartę w opiece nad dzieckiem w wieku przedszkolnym. Korzystając z metodologii badań historycznych, stosowanej w obszarze dociekań naukowych z historii wychowania, po przeprowadzeniu kwerendy archiwalnej, krytyce zewnętrznej i wewnętrznej źródeł historycznych, przygotowano monograficzne ujęcie zagadnienia dotyczącego rozwoju wychowania przedszkolnego w Polsce w XX wieku. W pracy wykorzystano analizę źródeł historycznych zachowanych w formie prasy fachowej, poradników metodycznych i literatury z zakresu wychowania przedszkolnego z okresu międzywojennego.

Wśród literatury omawiającej historię wychowania przedszkolnego, należy wymienić prace Wandy Bobrowskiej-Nowak pt. „Zarys dziejów wychowania przedszkolnego", która została wydana w 1978 roku, czy też publikacje autorstwa Marii Wróbel pt. „Wychowanie przedszkolne w Polsce w latach 1918-1939" wydanej we Wrocławiu w 1967 roku. Wśród prac naukowych z zakresu historii wychowania przedszkolnego warto też wspomnieć o artykułach naukowych Krzysztofa Jakubiaka 
o początkach wychowania przedszkolnego w Polsce oraz Agaty Samsel pt. „Wychowanie przedszkolne w latach 1918-1939” opublikowanym w 2003 roku w dwóch częściach na łamach czasopisma „Wychowanie w Przedszkolu", jak i o rozdziałach w publikacjach zwartych autorstwa Anny Klim- Kimaszewskiej, Danuty Waloszek, Jolanty Karbowniczek czy Zbigniewa Ostracha ${ }^{1}$. W obszarze bibliograficznym znajdują się także artykuły naukowe autorstwa Dariusza Szewczuka, Mirosławy Bednarzak-Libery czy Joanny Sosnowskiej omawiające rozwój ochron i przedszkoli w kontekście regionalnym i z uwzględnieniem specyfiki danego obszaru $^{2}$. Warto także wspomnieć o pracach naukowych, które pośrednio dostarczają cennej wiedzy o potrzebach dzieci w wieku przedszkolnym, tak jak artykuł Agnieszki Wałęgi ${ }^{3}$ ukazujący organizację opieki nad małym dzieckiem w kontekście działalności Pomorskiego Towarzystwa

1 K. Jakubiak, Początki polskiej pedagogiki przedszkolnej, „Edukacja Elementarna w Teorii i Praktyce”, 2015 nr 4(38), s. 109-118; A. Samsel, Wychowanie przedszkolne w latach 1918-1938 (cz. I), „Wychowanie w Przedszkolu”, 2003 nr 8, s. 463-466; (cz. 2) „Wychowanie w Przedszkolu”, 2003 nr 9, s. 518-522; A. Klim-Klimaszewska, Wychowanie przedszkolne we współczesnym systemie oświaty na tle rysu historycznego, Warszawa 2005; D. Waloszek, Historyczno-epistemologiczne podstawy pedagogiki przedszkolnej, Kraków 2006; J. Karbowniczek, Z historii wychowania przedszkolnego, w: Podstawy pedagogiki przedszkolnej z metodyka, red. J. Karbowniczek, M. Kwaśniewska, B. Surma, Kraków 2011, s. 9-80; Z. Ostrach, Rozwój praktyki przedszkolnej $w$ ujęciu historycznym, w: Praca przedszkola: wybrane zagadnienia teoretyczne, praktyczne i organizacyjne, red. Z. Ostrach, Kraków 2016, s. 9-31.

2 D. Szewczuk, Rola ochronek na Lubelszczyźnie $w$ wychowaniu dzieci na przełomie XIX i XX wieku, w: Virginibus puerisque, tom 2, Z zagadnień wychowania i opieki nad dzieckiem $w$ XVIII-XX wieku, red. E. Kula, M. Pękowska, Kielce 2012, s. 173-184; M. Bednarzak-Libera, Ochronki założone przez Towarzystwa Szkoły Ludowej placówkami przyjaznymi i przeciwdziałającymi wynaradawianiu polskich dzieci w Austro-Węrzech, w: Virginibus puerisque, tom 2, Z zagadnień wychowania i opieki nad dzieckiem w XVIII-XX wieku, red. E. Kula, M. Pękowska, Kielce 2012, s. 153-172; J. Sosnowska, Instytucje wychowania przedszkolnego w wielokulturowej Łodzi w latach 1924-1939. Organizacja, zadania, formy działania, „Wychowanie w Rodzinie", 2014 t. IX nr 1, s. 281-306.

3 A. Wałęga, Działalność opiekuńcza Pomorskiego Towarzystwa Opieki nad Dziećmi (1918-1948), w: Virginibus puerisque, tom 2, Z zagadnień wychowania i opieki nad dzieckiem w XVIII-XX wieku, red. E. Kula, M. Pękowska, Kielce 2012, s. 131-144. 
Opieki nad Dziećmi. Wymienione prace nie wyczerpują zasobu bibliograficznego omawianego zagadnienia, stanowią jednak bardzo cenne źródło wiedzy historycznej dotyczącej rozwoju wychowania przedszkolnego na gruncie polskim. Wychowanie przedszkolne w Polsce ma ponad stuletnią tradycję, która nie doczekała się do tej pory opracowania monograficznego. Wszystkie przytoczone propozycje artykułów nie stanowią jednak całościowego monograficznego ujęcia wychowania przedszkolnego. Również niniejszy tekst nie uzurpuje sobie prawa do takiego całościowego kompendium wiedzy, ma również charakter przyczynkarski. Jednocześnie zwracam uwagę na potrzebę opracowania monograficznego historii wychowania przedszkolnego z uwzględnieniem obecnie dostępnych materiałów źródłowych. Posiadając dostęp do źródeł archiwalnych i wykorzystując warsztat badawczy historyka należy opracować obiektywną i rzetelną monografię naukową.

\section{Ochronki - XIX-wieczny prototyp przedszkoli}

Nie można rozpocząć analizy wychowania przedszkolnego w kontekście historycznym bez uwzględnienie początków działalności przedszkoli. Prototypem przedszkoli były ochronki, które zostały zorganizowane w XIX wieku, jako efekt zmian społeczno-gospodarczych ówczesnej Europy. W wyniku rozwoju przemysłu i wzrostu zapotrzebowania na pracę kobiet coraz powszechniejszy stawał się problem opieki nad dziećmi matek pracujących zawodowo. Pierwsze ochronki zorganizowano najpierw w Anglii, w 1816 roku z inicjatywy utopisty Roberta Owena, a w 1824 roku Samuel Wilderspin, założył Towarzystwo Szkółek Dziecięcych (infant schools). Celem pierwszych angielskich ochronek było wyposażenie wychowanków w minimalny poziom wiedzy przydatnej w życiu codziennym.

Natomiast we Francji pierwsze ochronki powstały w wyniku działalności oświatowej ewangelickiego pastora Jean-Frédéric Oberlina. Ich zadaniem było zapewnienie dzieciom opieki oraz przygotowanie ich do szkoły elementarnej poprzez rozwijanie mowy i zamiłowania do pracy, systematyczności i porządku. Pierwsza ochronka na wzór angielskich Infant Schools powstała z inicjatywy Jana Cochina, autora cenionej 
książki pt. „Podręcznik dla założycieli i kierowników pierwszych szkół znanych pod nazwą ochron". Był to kompleks instytucji wychowawczych dla czterystu dzieci, obejmował: przedszkole, szkołę i seminarium dla wychowawców ochron. Pierwszą typową szkołę dla pracowników ochron założyła Maria Pape'-Carpantier, która opracowała również podręcznik pt. „Rady dla prowadzących ochrony”. Autorka poruszyła w nim zagadnienia właściwych metod kształcenia, opartych na kierowanej obserwacji przedmiotów i zjawisk z otaczającego świata. Proponowała, aby dzieci przypisywać do grup według ich wieku i zwiększyć liczbę personelu pedagogicznego.

Ochronki powstały także w Niemczech na początku XIX wieku i były wzorowane na angielskich i francuskich szkółkach. Jedną z pierwszych ochronek założyła Paulina Lippie-Detmold, wzorując się na placówkach przedszkolnych we Francji. W 1819 roku w Berlinie Fryderyk Wadzeck zorganizował ochronkę dla dzieci w wieku żłobkowym. Szersze inicjatywy w zakresie organizowania ochronek podjęli także Johann Georg Wirth w Augsburgu oraz Teodor Fliender w Keisersworth, którzy wzorowali się na szkółkach dla małych dzieci zakładanych w Holandii i Anglii. Rozkwit przedszkoli niemieckich, zwanych „ogródkami dziecięcymi" przypada na lata działalności Friedricha Wilhelma Fröbela (Froebel), teoretyka i głównego twórcy wychowania przedszkolnego o orientacji humanistycznej, inicjatora pierwszego systemu wychowania przedszkolnego.

We Włoszech pierwsza ochronka dla dzieci powstała w Cremonie w 1827 roku, założył ją Aporti Ferrante. Do placówki tej przyjmowane były dzieci z zamożniejszych rodzin. Organizowano dla nich ćwiczenia gimnastyczne, zajęcia kształcące zmysły i przeznaczano czas na swobodną zabawę. Jednak intensywny rozwój ochronek we Włoszech przypada na lata działalności Marii Montessori, lekarki i twórczyni systemu wychowania dzieci opartego na swobodnym rozwoju. Uważała, że głównym zadaniem pedagogiki jest wspieranie spontaniczności i twórczości dzieci oraz umożliwienie im harmonijnego i wszechstronnego rozwoju fizycznego, intelektualnego, moralnego i społecznego. Swoje poglądy i koncepcje pedagogiczne oparte na szacunku do dziecka i wspieraniu jego rozwoju wprowadzała z niebywałym sukcesem 
wychowawczym w pierwszym przedszkolu Casa dei Bambini założonym w 1907 roku w rzymskiej robotniczej dzielnicy San Lorenzo.

Również w Europie Wschodniej, w Rosji pierwsze ochrony zorganizowano w Petersburgu w 1837 roku. Placówki miały charakter filantropijny, były zakładane przez osoby prywatne a ich byt finansowy zależał od tzw. kuratora, zwykle bogatego kupca. Z czasem powołano komitet opiekuńczy, którego zadaniem było opracowanie regulaminów i zasad funkcjonowania ochronek na terenie Rosji.

Możliwości rozwoju opieki nad małym dzieckiem w Polski, były dość ograniczone ze względu na sytuację zaborową. Gdy w Europie ulegała zmianie struktura społeczna oraz gospodarcza i pojawiały się nowe koncepcje pedagogiczne oparte na nurtach wolnościowych, Polska musiała skoncentrować się głównie na zabezpieczeniu swojej narodowości wobec polityki państw zaborczych. Nie oznacza to jednak, że pozostawaliśmy poza nowymi koncepcjami i praktykami pedagogicznymi. Również na gruncie polskim, w trosce o losy dzieci zorganizowano w 1814 roku w Warszawskie Towarzystwo Dobroczynności, które pomagało sierotom oraz świadczyło pomoc materialną ubogim rodzinom. Na fundamencie działalności filantropijnej, pomysł założenia ochronek dla dzieci wysunął Teofil Janikowski wraz z Piotrem Łubieńskim i Stanisławem Jachowiczem. Pierwsza ochronka powstała w Warszawie w 1837 roku i wzbudziła zainteresowanie, a napływ dzieci wskazywał na potrzebę tego typu placówek. Kolejną założono rok później, a następną w 1839 roku. Odtąd liczba założonych ochronek stale wzrastała nie tylko w Warszawie, lecz i w innych miastach Królestwa Polskiego, a w 1870 roku odnotowano już trzydzieści dwie ochronki. Pierwotnie ochrony były organizowane przez instytucje filantropijne, towarzystwa dobroczynne, zakony, gminy protestanckie i żydowskie.

Na gruncie polskim w wyniku docierających z Europy Zachodniej poglądów pedagogicznych zaczęły przyjmować się koncepcje F. W. Frobla i M. Montessori. Jan Władysław Dawid i Stanisław Karpowicz w swoich pracach naukowych również zwracali uwagę na znaczenie wczesnego dzieciństwa w procesie rozwoju człowieka. Karpowicz przystosowując teorie do życia praktycznego, zorganizował w Warszawie eksperymentalny i nowoczesny „Dom Wychowawczy” dla dzieci w wieku przedszkolnym, w którym stosowano nowe metody pedagogiczne. 
Ochronki zakładano nie tylko w miastach, ale także i na wsiach. W 1842 roku działacz i myśliciel społeczny August Cieszkowski zwrócił uwagę na złe warunki, w jakich żyją dzieci na wsi, oraz na korzyści wynikające z rozwoju ochron wiejskich oraz wychowawczej opieki nad dziećmi wiejskimi. Od 1860 roku Towarzystwo Rolnicze zaczęło propagować wśród ziemiaństwa idee zakładania ochron zamiast szkół. Wtedy powstały setki ochron założonych przez powołane w 1855 roku Zgromadzenie Sióstr świętego Feliksa z Kantalicjo Trzeciego Zakonu Regularnego Świętego Franciszka Serafickiego. W zaborze rosyjskim ochronki nie podlegały władzy inspektorów szkolnych, były więc tajnymi ośrodkami szkolnymi, do których uczęszczały dzieci w wieku przedszkolnym jak i szkolnym w celu tajnego nauczania języka polskiego. Zadaniem ochron było przede wszystkim zapewnienie opieki dzieciom a także dbanie o ich wychowanie moralne i narodowe, co w ówczesnej sytuacji Polski było uzasadnione. Wraz z rozwojem przemysłu, powstało też szereg ochron przy zakładach przemysłowych, jak chociażby ochronka w Żyrardowie dla dzieci robotników fabrycznych. W Polsce do czasu odzyskania niepodległości funkcjonowały dwa rodzaje instytucji przedszkolnych: ochronki, w których dzieci matek pracujących otrzymywały opiekę i placówki przedszkolne wzorowane na ogródkach freblowskich lub domach dziecięcych M. Montessori. Od 1918 roku zaczęto wyznaczać jeden wspólny kierunek działalności obu tych instytucji.

\section{Status przedszkola w systemie oświatowym w Drugiej Rzeczypospolitej}

W okresie międzywojennym nadal stosowano, często zamiennie dwa określenia instytucji opieki nad dzieckiem w wieku przedszkolnym: ochronka i przedszkole. Ochronka nawiązywała głównie do funkcji opieki i ochrony dziecka i była bardziej osadzona w tradycji polskiej, natomiast przedszkole było nawiązaniem do ogródków freblowskich i placówek montessoriańskich, gdzie oprócz opieki poprzez zabawy i zajęcia dodatkowo rozwijano fizyczną i psychiczną strukturę dziecka. W rzeczywistości zmierzano, do naturalnego przekształcania ochronek 
na przedszkola, poprzez wprowadzanie gier i zajęć oraz przygotowanie metodyczne opiekunek w ochronkach.

Termin przedszkole został po raz pierwszy użyty w Polsce w 1919 roku podczas pierwszego Ogólnopolskiego Zjazdu Oświatowego, którego celem było opracowanie planów i strategii rozwoju oświaty w odrodzonym państwie polskim. Wówczas podczas tzw. Sejmu Nauczycielskiego utworzono Sekcję Wychowawczyń Przedszkoli, podjęto działania w celu uznania przedszkola jako placówki oświatowej, w której dziecko jest wychowywane i przygotowywane do edukacji szkolnej. Natomiast formalnie nazwa przedszkole została wprowadzona na drodze tak zwanej reformy jędrzejewiczowskiej i Ustawy o ustroju szkolnictwa z 11 marca 1932 roku, w której ustalano miejsce placówki przedszkolnej w ówczesnym systemie szkolnictwa.

W 1919 roku, po odzyskaniu przez Polskę niepodległości, Ministerstwo Wyznań Religijnych i Oświecenia Publicznego (dalej MWRiOP) stworzyło specjalny Referat Wychowania Przedszkolnego, który zalecił, aby w ochronach nie prowadzić nauki elementarnej, ale skoncentrować działania na zajęciach związanych z ochroną zdrowia dziecka. Co było podyktowane wysokim wskaźnikiem śmiertelności wśród małych dzieci w wyniku szerzącej się epidemii chorób zakaźnych, tj. gruźlica, jaglica czy dur brzuszny. Dbanie o higienę i zdrowie fizyczne wyznaczyło kierunek działalności przedszkolnej, w dużej mierze oparty na pracy w ochronkach. Zamiast programu z wychowania przedszkolnego obowiązywały dwa poradniki: jeden wydany w 1920 roku jako „Podręcznik dla ochroniarek” opracowany przez Polskie Towarzystwo Pedagogiczne przy współudziale Stanisława Progulskiego, Idy Marii Schätzel, Barbary Żulińskiej, Natali Cicimirskiej, Jadwigi Warchałowskiej, Marii Sarjusz-Jaworskiej i drugi wydany w 1921 roku pod tytułem: „Wskazówki dla osób zakładających i prowadzących ochrony (z planami budynków)" opracowany przez Marię Weryho-Radziwiłłowiczową. Podręcznik dla ochroniarek to było kompendium wiedzy z zakresu rozwoju biopsychicznego dziecka w wieku przedszkolnym, poruszono w nim kwestie związane z: higieną, odżywieniem i pielęgnacją, psychologią, wychowaniem i kształceniem, formami zajęć i za- 
baw oraz z informacjami o instytucjach opieki nad dzieckiem ${ }^{4}$. Natomiast w książce „Wskazówki dla osób zakładających i prowadzących ochrony (z planami budynków)" M. Weryho-Radziwiłłowiczowa określiła główny cel działalności ochrony, jakim miała być pomoc rodzicom w wychowaniu dzieci z zastosowaniem zasady koncentracji uwagi i poznawania otaczającej rzeczywistości poprzez aktywne angażowanie wszystkich zmysłów i dostosowywanie metod do potrzeb rozwojowych dziecka ${ }^{5}$. Radziwiłłowiczowa kontynuowała metody stosowane przez F. W. Froebla, dodając do tego jeszcze bogaty zbiór gier i zabaw na świeżym powietrzu. Poza tym, jak zauważył w swoim artykule Krzysztof Jakubiak „Nowoczesne, jak na tamte czasy było także twierdzenie M. Weryho-Radziwiłłowiczowej, że nie jest ważne to, co dzieci w swych zabawach i pracach wykonywały, ale to, co same przeżyły i czego się nauczyły"6. Za sprawą M. Weryho-Radziwiłłowiczowej powołano Towarzystwo Wychowania Przedszkolnego, wydawano czasopismo pt. „Wychowanie Przedszkolne”, opracowano wytyczne i założenia wychowania przedszkolnego, wyposażono przedszkola w niezbędne pomoce dydaktyczne, a także zorganizowano seminaria i kursy dla ochroniarek. Maria Weryho-Radziwiłłowiczowa wraz ze współpracowniczkami i zwolenniczkami nowych form wychowania małego dziecka ze Stefanią Marciszewską-Posadzową, Teresą z Pruszaków Mleczkową, Natalią Cicimirską, Fryderyką z Zielonków Grottową rozwijały nowe kierunki wychowania przedszkolnego. Zaangażowana w nowy nurt wychowania przedszkolnego była także Józefa Żukowska, założycielka pierwszej freblówki w Kielcach i Stanisława Okołowiczówna, nauczycielka, autorka książek dla dzieci i wizytatorka ochronek. Zapewne były jeszcze inne osoby zaangażowane w opiekę nad małym dzieckiem. Prawdopodobnie dochodziło do współpracy i wymiany poglądów i pomysłów wychowawczych pomiędzy Marią Weryho-Radziwiłłowiczową a Januszem Korczakiem i Marią Grzegorzew-

4 Podręcznik dla ochroniarek, red. S. Progulski, I. M. Schätzel, B. Żulińska, J. Warchałowska, M. Sariusz-Jaworska, Lwów 1920.

5 M. Weryho-Radziwiłłowiczowa, Wskazówki dla osób zakładających i prowadzacych ochrony (z planami budynków), Warszawa 1921.

${ }^{6}$ K. Jakubiak, Początki polskiej pedagogiki przedszkolnej..., s. 112. 
ską, ponieważ wspólnie należeli do Polskiego Komitetu Opieki nad Dzieckiem, wchodzili w skład zespołu redakcyjnego czasopisma „Opieka nad Dzieckiem” oraz byli współautorami serii „Zagadnień opieki nad macierzyństwem, dziećmi i młodzieżą w Polsce".

W wyniku wytężonej pracy społecznej, propagowania idei wychowania przedszkolnego w latach 1927/28 na terenie Polski funkcjonowało 1435 ochron, z czego 776 zorganizowano w miastach a 659 na terenach wiejskich. Łącznie do przedszkoli uczęszczało 83912 dzieci. Najmniej przedszkoli zorganizowano na Kresach Wschodnich, w województwie wileńskim w 1927 roku było zaledwie 8 przedszkoli na wsi i tylko 7 w samym Wilnie. Na pierwszym miejscu był powiat częstochowski, w którym było 88 przedszkoli wiejskich, do których uczęszczało ponad 4000 dzieci $^{7}$.

Do przedszkola przyjmowano dzieci w wieku od 3 do 7 lat. Ochronki wiejskie były przeważnie jednooddziałowe, a miejskie dwuoddziałowa ze względu na większą liczbę dzieci. Pierwszy oddział był dla dzieci w wieku od 3 do 5 lat, a do drugiego uczęszczały dzieci starsze, od 5 do 7 roku życia. Czas trwania zajęć, ferii i tryb dzienny w przedszkolach był różny i zależny od miejscowych warunków i potrzeb rodziców. W przedszkolach miejskich dzieci przebywały od godziny ósmej do piętnastej, a w miejscowościach fabrycznych lub na wsi, gdzie matki przebywały dłużej poza domem, ich dzieci pozostawały też dłużej w przedszkolu. Również ferie były uzależnione od specyfiki miejscowości, w miastach dzieci korzystały z przerwy wakacyjnej latem, a na wsi ferie organizowano zimą, gdy nie było prac polowych a śnieżne zamiecie i niska temperatura uniemożliwiały przyjście dzieci do placówki. Codzienny plan dnia też różnił się w przedszkolach miejskich i wiejskich. W południe dzieci z ochronek wiejskich i fabrycznych szły do domu na obiad, a w przedszkolach miejskich spożywały opłacony przez rodziców obiad (zupa, kasza, mleko) na miejscu.

W skład personelu przedszkola wchodziły: kierowniczka, wychowawczyni i służąca. Jeśli ochronka była dwuoddziałowa i jeżeli liczba dzieci przekraczała czterdzieści to wychowawczyni przydzielano po-

7 M. Weryho-Radziwiłłowiczowa, Zarys wychowania przedszkolnego, Warszawa 1930, s. 8-9. 
mocnicę. Do personelu zaliczano także higienistkę, która pomagała w zakresie opieki higieniczno-zdrowotnej. Zadaniem personelu przedszkolnego było stworzenie środowiska, w którym dziecko mogłoby nabywać nawyki kulturalne, rozwijać swoje zdolności wrodzone i przygotowywać się do przyszłej pracy szkolnej w atmosferze swobody, serdeczności i ciepła.

Cała atmosfera w przedszkolu zależała w głównej mierze od wychowawczyni, która odpowiadała za sukces pracy wychowawczej. Dobra wychowawczyni, jak uważała M. Weryho-Radziwiłłowiczowa, ,jest pogodna, kocha i rozumie dzieci, ma przygotowanie metodyczne i pedagogiczne, umie zając dziecko, włada dobrze językiem ojczystym, posiada znajomość nauk przyrodniczych, krajoznawstwa, zna dzieje Polski, posiada ogólne wiadomości z higieny, ogrodnictwa, jest muzykalna, umie rysować, modelować i zna się na ogrodnictwie. Wiadomości swe umie zużytkować w przedszkolu w sposób zajmujący, łatwy, z uwzględnieniem warunków rozwojowych dziecka, nie przyspieszając tempa rozwoju. Kierowniczka powinna powsiadać odpowiednie kwalifikacje pedagogiczne, ukończony kurs seminarium ochroniarskiego państwowego lub prywatnego z prawami państwowymi"8.

Trzeba przyznać, że oczekiwania stawiane wychowawczyniom przedszkoli były wygórowane, co wynikało z rozumienia znaczenia okresu przedszkolnego w dalszym rozwoju dziecka. Stąd od osoby zajmującej się dziećmi w ochronkach i przedszkolach wymagano wszechstronnej wiedzy, umiejętności praktycznych, ale także predyspozycji psychicznych i osobowościowych. Zawód „przedszkolanki” w okresie międzywojennym dopiero kształtował się, aby przygotować kompetentne wychowawczynie organizowano kursy dla ochroniarek. Za miesiąc swojej pracy wychowawczyni w przedszkolu wiejskim otrzymywała pensję w wysokości 150 zł, a pracując w przedszkolu w mieście, mogła zarobić od 150 do 300 złotych $^{9}$. Czy było to dużo, biorąc pod uwagę warunki pracy i wymagania stawiane wobec kandydatek na wychowawczynie przedszkolne? Dla porównania, można podać, że zarobki robotnika wykwalifikowanego wynosiły około 120 złotych za miesiąc,

\footnotetext{
8 M. Weryho-Radziwiłłowiczowa, Zarys wychowania..., s. 20.

9 Tamże.
} 
a pracownika umysłowego 280 złotych. Przy czym bochenek chleba kosztował wówczas 0,30 złotych, a kilogram cukru 1 złotych ${ }^{10}$.

W okresie międzywojennym strukturalnie określono formę organizacji przedszkoli, ale nie sprecyzowano wtedy jeszcze ich funkcji i roli w korelacji ze szkołą. Zapewne brakowało podstaw psychologicznych i pedagogicznych z zakresu wychowania przedszkolnego, a także społecznej świadomości znaczenia opieki i wsparcia wychowawczego dziecka w wieku przedszkolnym. Próba ugruntowania pozycji przedszkola w systemie oświatowym spotkała się z trudnościami natury finansowej. Polityka oświatowego państwa polskiego skupiła się wówczas na upowszechnianiu szkoły, co związane było z wysokim poziomem analfabetyzmu, jak i potrzebą rozbudowania sieci szkół, co wiązało się z wysokimi nakładami finansowymi z budżetu państwa. Sytuację tę pogorszył jeszcze kryzys gospodarczy w latach 30. XX wieku, który znacznie zahamował rozwój instytucji społecznych i oświatowych, w tym także przedszkoli. Można przypuszczać, że również mniejszości narodowe i grupy wyznaniowe, których wówczas w Polsce było ponad 34 \% zakładały swoje prywatne placówki przedszkolne. Żłobki, przedszkola, ochronki i cały system opieki nad matką i dzieckiem powierzono prywatnym stowarzyszeniom, organizacjom i związkom wyznaniowym. Sprawa wychowania przedszkolnego zajmowała pedagogów w okresie międzywojennym. Związek Polskiego Nauczycielstwa Przedszkoli i Wychowawców powołał w 1937 roku Towarzystwo Przyjaciół Przedszkoli, którego celem było propagowanie wychowania przedszkolnego wśród społeczeństwa.

10 J. Parchimowicz, T. Borkowski, Katalog banknotów polskich i z Polska związanych, Warszawa 2001; Z. Landau i J. Tomaszewski, Spory o ocene tendencji rozwoju gospodarki polskiej w latach 1918-1939, „Przegląd Historyczny”, 1984 nr 75/4, s. 723-746; tenże, Trudna niepodległość. Rozważania o gospodarce Polski 1918-1939, Warszawa 1978; T. Jabłoński, Polski pieniądz papierowy 1794-1948, Warszawa 1964. 


\section{Teoretyczno-praktyczne założenia wychowania przedszkolnego w ujęciu Marii Weryho-Radziwiłłowiczowej}

Omawiając założenia teoretyczno-praktyczne wychowania przedszkolnego w okresie międzywojennym, nie sposób pominąć poglądów pedagogicznych Marii Weryho-Radziwiłłowiczowej (1858-1944), głównej inicjatorki wychowania przedszkolnego. Uważała, że nauczanie przedmiotów szkolnych nie powinno stanowić bezpośredniego zadania przedszkola, którego celem miało być wyłącznie wychowanie, tj. budzenie uczuć religijnych, społecznych i estetycznych oraz ćwiczenia zmysłów, uwagi, pamięci, spostrzegawczości, wyobraźni, mowy oraz nawyków. Wychowanie przedszkolne miało stanowić pierwszy etap wpajania i zapoznawania z wartościami patriotycznymi zgodnie z ideologią wychowania państwowego ${ }^{11}$. Praca wychowawcza nie mogła być przypadkowa, ale musiała być prowadzona planowo i metodycznie. Wszystkie zajęcia miały być dostosowane do natury dziecka, jego zainteresowań wobec otoczenia, środowiska, praw natury. W rzeczywistości treści były nacechowane encyklopedyzmem, ale przekazywane były poprzez rozmowy, pogadanki, ćwiczenia spostrzegawczości, opowiadania, naukę wierszy, ćwiczenia zmysłów, zajęcia z rysunku, modelowanie, wycinanie, budowanie, gry i zabawy, ćwiczenia fizyczne, spacery, wycieczki, śpiewy. Rozmowy i pogadanki miały na celu pobudzenie dziecka do spostrzeżeń i doświadczeń. Z małymi dziećmi, w wieku 3-4 lat, rozmowy prowadzono indywidualnie, a ze starszymi grupowo lub zbiorowo. Ważny środek wychowawczy stanowiły opowiadania, o rozmaitej i zróżnicowanej treści fantastyczno-etycznej i przyrodniczej.

Bardzo zróżnicowane formy przekazu były dostosowane do potrzeb i możliwości dzieci, ale także uwzględniały etapy rozwoju społecznego, fizycznego i intelektualnego dziecka. M. Weryho-Radziwiłłowiczowa kładła bardzo duży nacisk, na rozwój uczuć społecznych, czyli sto-

11 A. Samsel, Wychowanie patriotyczne $w$ przedszkolach II Rzeczypospolitej, w: Kobieta a patriotyzm. Konteksty historyczno-pedagogiczne XVI-XX wieku, red. E. J. Kryńska, Ł. Kalisz, A. Konopacki, Białystok 2012, s. 121-134. 
sunek dziecka do pracy, zjawisk społecznych i osób z otoczenia. Samo otoczenie rówieśników było najlepszym środowiskiem dla uspołecznienia dziecka, dla wyrobienia w nim uczuć moralnych. Obok wpajania uczuć społecznych, wychowawczyni wdrażała dziecko do kulturalnych przyzwyczajeń, jak wyrobienie nawyku czystości i porządku, grzeczności, uprzejmości, życzliwości.

Dostrzegała naturalną potrzebę dziecka do ruchu, sprawności i wytrzymałości fizycznej, ale także do aktywności i pracy, pokonywania trudności, zdolności plastycznych, modelowania, wycinania czy orientacji przestrzennej. Prekursorka wychowania przedszkolnego zwracała także uwagę na naturalną potrzebę ruchu u dzieci. Uważała, że ćwiczenia fizyczne muszą być ciekawe i oparte na grach i zabawach, bo tylko w taki sposób będą wyrabiać w dziecku zręczność, sprawność fizyczną, lekkości w odtwarzaniu ruchów. Ponadto ćwiczenia fizyczne i gry towarzyskie przyzwyczajały do solidarności i wdrażały do życia społecznego, utrzymywały energię cielesną, wpływały dodatnio na duchowy nastrój, dawały uczucie zadowolenia i radości. W przedszkolach dzieci ćwiczyły na drabinkach, ławkach, z piłkami, grały w podchody i gry zręcznościowe, naśladownicze, towarzyskie oraz rzutne samodzielnie wymyślane. Do ćwiczeń fizycznych zaliczano także prace ogrodowe, jak gracowanie ścieżek, kopanie, grabienie liści i gałęzi, skopywanie grządek, sadzenie, podlewanie. M. Weryho-Radziwiłłowiczowa dbała również o sprawność psychiczną dziecka, rozwijała w nim bystrość, ciekawość, zainteresowania, inicjatywę, postrzeganie, uwagę, pamięć, rozumienie i wyobraźnię ${ }^{12}$. Podstawą poznawania przez dziecko otaczającej go rzeczywistości były zmysły, które w przedszkolu miały być cały czas uwrażliwiane i uaktywniane. Przy zapoznawaniu się z otoczeniem, organy zmysłów czyli oko, ucho, ręka, smak i powonienie były w ciągłym użyciu. Dziecko rozszerzało swoją wiedzę, nie tylko przez patrzenie, ale przez działanie, tj. odtwarzanie swych spostrzeżeń, uplastyczniając je w rysunku, w wycinaniu lub modelowaniu. Poprzez badanie świata przez zmysły dziecko chętniej nazywało to, co widziało, co sprzyjało w rozwoju mowy, tak charakterystycznej dla wieku przed-

12 M. Weryho-Radziwiłłowiczowa, Zarys wychowania...., s. 14. 
szkolnego. Słownik dziecka wzbogacał się każdego dnia poprzez wyliczanie przedmiotów, ćwiczenie zmysłów, rozmowę, opowiadania, oglądanie obrazków, uczenie się wierszy i poprzez wszelkie zabawy, które były źródłem ćwiczeń językowych. Jednak to od dorosłego zależała intensywność rozwoju zmysłów dziecięcych, ponieważ to wychowawca dostarczał odpowiednich pomocy oraz wzbogacał otoczenie takimi bodźcami, na które reagowały zmysły dziecka.

Maria Weryho-Radziwiłłowiczowa zwracała także uwagę na naukę praktycznych umiejętności. Prace ręczne nie tylko wyrabiały sprawność ręki, ale także zmuszały do obserwacji, sprzyjały rozwojowi centrów mózgowych. Koszyczki z rafii, laleczki z bibułki, pudełeczka, wózki, pajace z papieru pobudzały zainteresowanie, uświadamiały cel i pobudzały twórczość. Tak zwany slojd (nauka zręczności), czyli skandynawski system prac ręcznych w drewnie, glinie, wiklinie i tekturze już w okresie międzywojennym był wprowadzany na poziomie wychowania przedszkolnego i w szkołach powszechnych. Na marginesie warto wspomnieć, że jest to obecnie jedna z podstawowych form pracy w przedszkolach i szkołach skandynawskich, a prace ręczne ponownie powracają do szkół europejskich i stanowią alternatywę wobec zajęć komputerowych.

Okres przedszkolny sprzyjał także rozwojowi poczucia estetyki poprzez naturalną potrzebę piękna, dlatego tak ważne były odpowiednie bodźce takie jak: śpiew, tańce, gimnastyka rytmiczna. W przedszkolach i ochronkach dzieci często spędzały czas na powietrzu, co rozwijało w nich poczucia piękna otaczającej natury i organizowano im wycieczki, spacery niezależnie od pory roku. Ponadto dzieci poznawały przyrodę podczas działań tj. pielęgnowanie kwiatów, uprawa zagonków, układanie wiązanek, zapoznawanie z florą i fauną miejscową, hodowlę zwierząt, badanie życia owadów.

M. Weryho-Radziwiłłowiczowa w swoich poglądach z zakresu wychowania przedszkolnego niewątpliwie bazowała na koncepcjach naturalizmu $^{13}$, jak i nowego wychowania, kontynuowała myśl pedagogiczną F. W. Froebla, ale także stosowała metodę M. Montessori, polegającą

13 „Wychowanie Przedszkolne”, 1938 nr 2, s. 4-8. 
na skupianiu się na potrzebach dziecka, akceptacji i umożliwieniu mu samodzielności oraz nauki przez działanie instynktowne ${ }^{14}$ i poprzez zmysłowe doświadczanie i poznawanie świata ${ }^{15}$. Ponadto w poglądach M. Weryho-Radziwiłłowiczowej można zauważyć także elementy psychologii indywidualnej Alfreda Adlera, szczególnie te ukazująca warunki harmonijnego rozwoju dziecka, poczucie wartościowości i zrozumienie $^{16}$. Sama jednak rozwinęła bardzo mocno kwestie związane $\mathrm{z}$ naturalną potrzebą ruchu $\mathrm{u}$ dzieci $\mathrm{w}$ wieku przedszkolnym i wykorzystała cechy przyrodnicze do rozwoju biopsychicznego dziecka.

Warto jeszcze zwrócić uwagę na warunki, jakie miały panować w przedwojennym przedszkolu. Wybór miejsca na przedszkole nie był przypadkowy, teren na budowę przedszkola musiał być przestrzenny, miejsce zaciszne i z dostępem do świeżego powietrza i słońca. Przed budynkiem miał znajdować się plac zabaw oraz ogródek do sadzenia i pielęgnowania kwiatów i warzyw. Natomiast w budynku: sala zajęć, jedna lub dwie w zależności od liczby dzieci, pokój zabaw do gier i do leżakowania, pokój kierowniczki, służącej, szatnia na ubrania dziecięce, pokój kąpielowy z umywalką, kuchnia i ubikacja. Pokoje miały być wysokie, zgodnie z przepisami higienicznymi na jedno dziecko przypadał $1 \mathrm{~m}^{2}$ powierzchni, duże okna zajmujące $1 / 3$ powierzchni ściany od podłogi. Ściany zalecano, aby malować na jasny ciepły kolor i zabezpieczać 1,5 metra od podłogi drewnianym obiciem lub farbą olejną. W szatni znajdowały się wieszaki z półeczką u góry i małymi przegródkami na obuwie u dołu. Na półeczkach dzieci miały swoje znaczki (kwiatek, zwierzątko, sprzęt itd.). W ochronkach wiejskich dzieci nie zmieniały obuwia, a na środki szatni stał niski, owalny stołek, dookoła którego na haczykach były zawieszone ściereczki i szczoteczki do czyszczenia obuwia. Były też szczotki do czyszczenia ubrania i przyrządy do sprzątanie tj. małe szczoteczka do zamiatania, śmietniczka, ściereczka do kurzu. Przy umywalkach były wieszaki z ręcznikami, a na półkach kubeczki do płukania ust. W większych przedszkolach, np. w Skierniewicach dzieci korzystały ze składanych łóżeczek, zimą rozstawianych

14 „Wychowanie Przedszkolne”, 1936 nr 5, s. 12.

15 Podręcznik ochroniarski..., s. 180.

16 „Wychowanie Przedszkolne”, 1931 nr 1, s. 5-6. 
w sali rekreacyjnej, a latem w ogrodzie. Po obiedzie zwykle przez godzinę dzieci leżakowały w spokoju. Ponadto na wyposażeniu przedszkola była też duża szafa do przechowywania pomocy wychowawczych oraz biblioteczka i apteczka podręczna ${ }^{17}$.

Każde dziecko w przedszkolu otrzymywało pudełko, wielkości zeszytu lub szufladę w szafie, która była jego własnością na czas pobytu w przedszkolu, gdzie przechowywał swoje prace, zeszyty, ołówki, kredki i różne drobiazgi. Pudełka miały swoje odrębne znaczki, co rozbudzało poczucie porządku, autonomii i własności. Przedszkola stopniowo zatracały swój ponury charakter, dzięki temu, że usunięto duże stoły i ławki szkolne i stworzono atmosferę domu rodzinnego. W klasach były niskie stoliki, przy których na małych krzesełkach siedziało zazwyczaj czworo dzieci, a na środku stolika stała doniczka lub wazonik z kwiatem, przekazane pod opiekę dzieciom. W takich warunkach dzieci mogą swobodnie poruszać się, pracować, bawić, naradzać się lub rozmawiać, nie przeszkadzając innym. Każdy pokój dziecięcy miał swój odrębny charakter, odzwierciedlał gust artystyczny wychowawczyni, jej metody wychowawcze oraz zamiłowania i zainteresowania jej wychowanków. Na ścianach zawieszone były obrazki rodzajowe o treści lokalnej, zbiór pocztówek, odpowiednio dobranych, sezonowe rysunki, wykonane przez wychowawczynię, wycinanki, kolekcja lalek własnoręcznie sporządzonych, wazonik i doniczki z kwiatami, co stwarzało wrażenie miłego i przyjaznego otoczenia. Nisko na ścianach, na wysokości wzroku dziecka rozwieszone były rozmaite rysunki i prace dzieci. W każdej klasie dzieci miały swój kącik większy lub mniejszy, uboższy lub bogatszy, zależnie od zasobów materialnych zakładu. U dzieci najmłodszych był kącik z zabawkami (lalki, mebelki, gospodarstwo, zwierzęta, wózki) a u starszych książki, obrazki i albumy.

Wzdłuż ścian sali rekreacyjnej rozwieszane były pomoce, przyrządy do ćwiczeń i zabaw tj. piłki, skakanki, obręcze, kije do zabaw samorzutnych. W przedszkolach miejskich coraz częściej w sali znajdował się fortepian. Przedszkole starało się zaszczepić poczucie czystości i porządku, dlatego dzieci były ubrane w fartuszkach, posiadały własne

17 MWRiOP, Przedszkola Teren Urzadzenia terenowe Budynek i jego wykonanie Urządzenia pomieszczeń, Warszawa 1935. 
chustki do nosa, wstążeczki na głowę dla dziewczynek, oraz pantofle kapcie, których używali tylko w przedszkolu, a co stanowiło tak zwaną wyprawkę od przedszkola.

Kwestia higieny była równie ważna, jak inne aspekty wychowania przedszkolnego. Szczególnie w zakładach dziecięcych nie lekceważono zwyczajnego kataru lub zapalenia gardła, gdyż wiadomo było, że pod postacią tych pozornie niewinnych dolegliwości kryły się najpoważniejsze choroby zakaźne, takie jak: koklusz, błonica, gruźlica, odra itd. $\mathrm{W}$ razie podejrzenia o chorobę zakaźną, osoba dozorująca musiała natychmiast odesłać dziecko w towarzystwie osoby starszej (a nie drugiego dziecka!) do domu. Do ochronki nie mogły uczęszczać dzieci z domów, gdzie panowała choroba zakaźna. Przyjęcie dziecka do ochronki, po przebyciu choroby zakaźnej było decyzją podejmowaną przez lekarza po przeprowadzeniu szczegółowego badania. W ochronkach czy przedszkolach, aby uniemożliwić rozprzestrzenianie się chorób należało unikać przepełnienia i dbać o zasady higieny w codziennych czynnościach ${ }^{18}$.

\section{Podsumowanie}

Okres międzywojenny rozpoczyna nowy etap w rozwoju wychowania przedszkolnego. Przez ponad 123 lata zaborów warunki polityczne, społeczne i ekonomiczne nie sprzyjały rozwojowi wychowania przedszkolnego. W świadomości społecznej ochronki były miejscem opieki zabezpieczającym dziecko przed niebezpieczeństwem i brakiem dozoru domowego, a nie miejscem, gdzie realizowano metodyczne działania wychowawcze. W okresie międzywojennym dokonano zasadniczych zmian strukturalnych, organizacyjnych i jakościowych w funkcjonowaniu przedszkoli. Wraz z rozwojem wychowania przedszkolnego na świecie, rozwijała się psychologia dziecka, szukano drogi racjonalnego wychowani w psychologii teoretycznej i eksperymentalnej. Na nowej wiedzy budowano nowe teorie i działania pedagogiczne w zakresie wychowania przedszkolnego, krytykując jednocześnie obowiązujące przestarzałe metody. Maria Weryho-Radziwiłłowiczowa uważała, że wy-

18 Podręcznik ochroniarski..., s. 33. 
chowanie przedszkolne jest najważniejszym okresem w życiu dziecka, ponieważ ono toruje drogę myślom, pragnieniom i działaniom. Wychowawca w latach późniejszych dostaje w dziecku materiał już nie $\mathrm{w}$ pierwotnym stanie natury, ale z pewnymi przyzwyczajeniami, nieraz bardzo silnymi i musi często naprawiać, prostować i zmieniać. W wieku przedszkolnym jest tylko naturę dziecka, stąd łatwiej o wyrobienie nawyków. Celem wychowania przedszkolnego było, więc postawienie dziecko na właściwej drodze, dla późniejszego doskonalenia i wychowania cech wrodzonych ${ }^{19}$. Ważne $\mathrm{w}$ wychowaniu przedszkolnym była postawa wychowawcy, czy potrafił pobudzać dzieci do działania czy tylko narzucał dzieciom pomysły. Jednocześnie wychowawczyni musiała współpracować z rodziną dziecka, umiejętnie prowadzić zebrania i spotkania z rodzicami oraz wywiady w domu rodzinnym ${ }^{20}$.

Okres międzywojenny to imponujący czas w rozwoju przedszkoli, to okres budowania teorii i praktyki wychowania przedszkolnego. W tym czasie nadano ochronom właściwy charakter, usunięto nauczanie i przeniesiono dzieci siedmioletnie do szkoły. Zorganizowano zajęcia higieniczne i zapewniono etaty higienistkom, zaopatrzono przedszkola w odpowiednie pomoce wychowawcze. Wprowadzono obowiązek podnoszenia kwalifikacji pedagogicznych personelu, posiadania egzaminu z certyfikatem. Upaństwowiono kursy dla wychowawczyń i zorganizowano kursy wakacyjne dla instruktorek w Państwowym Seminarium Ochroniarskim w Krakowie, Lwowie, Warszawie, Częstochowie, Poznaniu, Mysłowicach, Wilnie i Opatówku.

Jednak w wyniku kryzysu gospodarczego, braku świadomości społecznego znaczenia przedszkoli, ich imponujący rozwój w okresie międzywojennym został zahamowany w latach 30. XX wieku. W 1926 roku zlikwidowano referat przedszkolny przy MWRiOP, pozostawiając naczelny nadzór nad seminariami a kwestie organizacji i utrzymania ochron przekazano samorządom (sejmikom, gminom i magistratom). Pozostawiono tylko dwa państwowe przedszkola, wzorcowo zorganizowane w Warszawie i Nałęczowie, które miały stanowić wzór godny naśladowania. Pomimo zapotrzebowania i wzrostu liczby przedszkoli ich

19 Tamże, s. 133-134.

20 „Wychowanie Przedszkolne”, 1934 nr 5, s. 2. 
rozwój od lat trzydziestych był stopniowo ograniczany i zupełnie zakończony w wyniku wybuchu drugiej wojny światowej.

Nie wiadomo, jaki los spotkał przedszkola podczas wojny i okupacji, literatura milczy w tym obszarze, można jedynie snuć przypuszczenia, że zostały zamknięte lub przemianowane na sierocińce i dzieci spotkał tragiczny los. Jest to kolejna biała plama badawcza, która wymaga wypełnienia.

Zakończenie drugiej wojny światowej stopniowo rozpoczęło kolejny etap rozwoju wychowania przedszkolnego w Polsce Rzeczpospolitej Ludowej (PRL). Wiadomo, że w 1945 roku na Ogólnopolskim Zjeździe Oświatowym w Łodzi wysunięto postulat w sprawie obowiązkowego wychowania przedszkolnego dla dzieci od 3 do 6 lat oraz utrzymania przedszkoli przez samorządy. Celem przedszkoli w PRL-u było stworzenie warunków do wszechstronnego rozwoju dzieci, przysposobienia ich do życia społecznego oraz do wykonywania obowiązku szkolnego. Wyraźna była tendencja do centralizacji w zarządzaniu przedszkolami, a działalność ich ujednolicono i podporządkowano systemowi oraz przemianom ustrojowym państwa. W latach 60. zlikwidowano przedszkola prowadzone przez organizacje społeczne i katolickie, jednocześnie rozszerzając sieć przedszkoli państwowych. Główną przyczyną organizacji przedszkoli był wzrost liczby pracujących kobiet i wypływające $\mathrm{z}$ tego zadania społeczne związane z obowiązkowym wychowaniem przedszkolnym pięciolatków. Od 1958 roku zaczęły powstawać ogniska przedszkole oraz przedszkola przy szkołach podstawowych, zorganizowano Studium Wychowania Przedszkolnego, gdzie kształcono kandydatów na wychowawców przedszkolnych. Ustawa o rozwoju oświaty $i$ wychowania z 15 lipca 1961 roku określiła wychowanie przedszkolne, jako pierwszy szczebel w jednolitym systemie oświaty i wychowania oraz ustaliła cele wychowania przedszkolnego, zwracając uwagę na wszechstronny rozwój dzieci, przygotowanie ich do nauki w szkole i pomoc pracującym rodzicom w zapewnieniu opieki wychowawczej. Ustawa była podstawą opracowania programu wychowania przedszkolnego oraz statutu przedszkola wprowadzonego w życie w 1963 roku. Przedszkole w PRL-u było pierwszym szczeblem w jednolitym systemie wychowania socjalistycznego i były pod ścisłą kontrolą kuratorów oświaty. W celu upowszechnienia przedszkoli od 1977 roku obowiązko- 
we wychowanie przedszkolne obejmowało dzieci sześcioletnie, dla których przygotowano program pracy oparty na nauce wszystkich liter alfabetu. Spowodowało to szeroką publiczną dyskusję na temat czy nauka nie zdominuje podstawowego czynnika wychowawczego małych dzieci, jakim jest zabawy. Pod koniec lat 70 . XX wieku opieką przedszkolną objęto 94,1\% dzieci sześcioletnich i tylko 24,9\% trzylatków.

Tuż przed rozpoczęciem transformacji ustrojowej w Polsce, w 1987 roku funkcjonowało 26 tysięcy przedszkoli, które zapewniały opiekę 415286 dzieciom. Zwiększono ich liczbę na terenach wiejskich, ale także zwiększono liczbę dzieci w grupach, co wpłynęło bezpośrednio na poziom realizowanych zadań opiekuńczych, wychowawczych i dydaktycznych w przedszkolach. Dokonano zmian programowych, które dotyczyły głównie modernizacji programu dla sześciolatków w zakresie elementarnej nauki czytania, przygotowania do nauki pisania i rozumienia pojęć matematycznych. Przedszkola prowadzone były przez terenowe organa administracji państwowej, państwowe lub spółdzielcze zakłady pracy, organizacje społeczne np. Towarzystwo Przyjaciół Dzieci oraz przez niektóre resorty np. Ministerstwo Obrony Narodowej, Ministerstwo Transportu i Komunikacji, Ministerstwo Rolnictwa i Gospodarki Żywieniowej. Pod koniec lat osiemdziesiątych, znaczenia nabrał społeczny ruch nauczycieli, rodziców i pracowników wyższych uczelni, wyrażający własną wizję edukacji dzieci i młodzieży. Co zaowocowało, powołaniem w 1989 roku Społecznego Towarzystwa Oświatowego, którego zadaniem było tworzenie autonomicznych szkół i przedszkoli społecznych, integracyjnych o dużej różnorodności organizacyjnej i autorskich programach pracy wychowawczej i dydaktycznej. Okres transformacji społecznej przyniósł szereg zmian programowych i organizacyjnych w funkcjonowaniu opieki nad dzieckiem w przedszkolach państwowych. Zgodnie z Ustawą z 7 września 1991 roku o systemie oświaty, do zakładania, prowadzenia i utrzymywania przedszkoli publicznych na swoim terenie zostały zobowiązane władze gminne. W wyniku, rozwijającej się gospodarki rynkowej, wzrostu bezrobocia wśród kobiet, ograniczenia środków finansowych na funkcjonowanie placówek oświatowych i opiekuńczych oraz odmienne pojmowanie ich dotychczasowych funkcji społecznych stopniowo następowała jednak likwidacja przedszkoli. Jednak w ostatnich latach obserwujemy ponow- 
ny „renesans” w rozwoju sieci przedszkoli i placówek opieki nad małym dzieckiem. Na początku lat 90. pojawiły się dwie krańcowe postawy wobec przedszkoli. Jedna z niechęcią traktująca przedszkola, jako „przeżytek komunizmu” czy jako „ochronkę”, a druga wskazująca na stymulujące znaczenie przedszkola dla rozwoju dziecka. Tak dualistyczne ujęcie przedszkola, szczególnie współcześnie, gdy obserwujemy intensywny rozwój ilościowych placówek przedszkolnych wymaga weryfikacji. Przy wielości i różnorodności, placówek przedszkolnych pojawiają się także pytanie o kierunek i znaczenie współczesnego wychowania przedszkolnego.

Na podstawie przywołanych powyżej faktów historycznych, które mam nadzieję, że nie zanudziły Czytelnika, można wywnioskować, że na przestrzeni lat przedszkola zmieniały się pod wpływem różnych koncepcji pedagogicznych oraz w zależności od obowiązującego ustroju w państwie. Od placówek o charakterze opiekuńczym przechodziły do instytucji wychowawczo-dydaktycznych, stanowiących pierwszy szczebel edukacji. Niewątpliwie jest to bardzo ważny i kulturotwórczy element dziedzictwa pedagogicznego. Kończąc ten artykuł, odwołam się ponownie do pytania: Czy na pewno przedszkole to relikt PRL-u? A może to niedocenione dziedzictwo pedagogiczne okresu międzywojennego, z którego nie potrafimy czerpać inspiracji i obdarzać szacunkiem. Z przykrością trzeba stwierdzić, że brakuje nam zdrowej i zrównoważonej społecznej dumy z naszych osiągnięć pedagogicznych i że nadal w obszarze historii wychowania przedszkolnego jest bardzo dużo niejasności, które wymagają badań i rzetelnego ujęcia monograficznego. Jednak to, że tak jest, to powód do podejmowania kolejnych wyzwań badawczych i społecznych. 


\section{Bibliografia:}

\section{Materiały źródłowe}

Cicimirska, Natalia. Moja ochronka. Podręcznik metodyczny Zbiór pogadanek i pieśni. Warszawa, Lwów: Księgarnia Gubrybowicza i Syna, 1928.

Dzierzbicka, Maria. „Zakładanie prywatnych przedszkoli”. Wychowanie Przedszkolne 2 (1934): 41-43.

Girtlerowa, Helena. „Przedszkole w Polsce”. Życie Dziecka 1 (1932): 3-9.

Kornecki, Jan. „Szkolnictwo powszechne w cyfrach z r. 1929/30”. Szkoła 8 (1931): 207-214.

Kozłowska, Anna. „Co wychowanie przedszkolne może dać dziecku”, Przyjaciel Szkoty 14 (1927): 621-624.

Progulski, Stanisław. Podręcznik dla ochroniarek. Lwów: Polskie Towarzystwo Pedagogiczne, 1920.

Mączeński, Zdzisław. Przedszkola Teren Urządzenia terenowe Budynek i jego wykonanie Urządzenia pomieszczeń. Warszawa: Ministerstwo Wyznań Religijnych i Oświecenia Publicznego, 1935.

Schätzel, Ida Maria. Idea wychowania przedszkolnego. Casa dei Bambini jako szkółka wszechstronnej pracy dziecka. Lwów: Polskie Towarzystwo Pedagogiczne, 1919.

Strzemeska, Justyna, Weryho Maria. Wychowanie przedszkolne. Podręcznik dla wychowawców. Lwów: Księgarnia Teodora Paprockiego, 1895.

Weryho-Radziwiłłowiczowa, Maria, Zarys wychowania przedszkolnego. Warszawa: Polski Komitet Opieki nad Dzieckiem, 1930.

Weryho, Maria. Wskazówki dla osób zakładających i prowadzacych ochrony (z planami budynków). Warszawa: Bibljoteka Polska, 1921.

Weryho-Radziwiłłowiczowa, Maria. Jak zajać dzieci $w$ wieku przedszkolnym. Pogadanki, rozmowy, robótki. Warszawa-Lublin-Łódź-Kraków: Gebethner i Wolff, 1900.

Wołowska, Zofia. „System daltoński a przedszkole”, Wychowanie Przedszkolne 12 (1929): 824-829.

Żukiewiczowa, Zofia. Wychowanie przedszkolne. Wskazówki metodyczne uwzględniające zainteresowanie dziecka. Lwów: „Książnica-Atsas”, 1924. 


\section{Literatura przedmiotu}

Bednarzak-Libera, Mirosława. „Ochronki założone przez Towarzystwa Szkoły Ludowej placówkami przyjaznymi i przeciwdziałającymi wynaradawianiu polskich dzieci w Austro-Węgrzech". W: Virginibus puerisque, tom 2, Z zagadnień wychowania i opieki nad dzieckiem $w$ XVIII-XX wieku, red. Ewa Kula, Marzena Pękowska, 153-172. Kielce: Wydawnictwo Uniwersytetu Jana Kochanowskiego, 2012.

Bilewicz-Kuźnia, Barbara. "Universal values of Friderich Froebel's Pedagogy In the views of polisch Froebelians" (Uniwersalne wartości pedagogiki Fridericha $\mathrm{w}$ poglądach polskich Froeblistów). Prima Educatione 2 (2018): 67-75.

Bobrowska-Nowak, Wanda. Historia wychowania przedszkolnego. Warszawa: Wydawnictwo Szkolne i Pedagogiczne, 1983.

Bobrowska-Nowak, Wanda. Zarys dziejów wychowania przedszkolnego: Materiały pomocnicze dla zakładów kształcenia nauczycieli przedszkoli cz. 1, 2. Warszawa: Wydawnictwo Szkolne i Pedagogiczne, 1978.

Domżał Urszula A. Opieka państwa i organizacji pozarządowych nad dzieckiem w latach 1919-1939. Łódź: Wyższa Szkoła Edukacji Zdrowotnej w Łodzi, 2009.

Jabłoński, Tadeusz. Polski pieniądz papierowy 1794-1948. Warszawa: Nakładem Koła Numizmatycznego, 1964.

Jakubiak, Krzysztof. „Początki polskiej pedagogiki przedszkolnej”, Edukacja elementarna $w$ Teorii i Praktyce 4(2015): 109-118.

Karbowniczek, Jolanta, „Z historii wychowania przedszkolnego”. W: Podstawy pedagogiki przedszkolnej z metodyka, red. Jolanta Karbowniczek, Małgorzata Kwaśniewska, Barbara Surma, 9-80. Kraków: Akademia Ignatianum Wydawnictwo WAM, 2011.

Kasáčová, Bronislava, Edukacja dzieci w wieku przedszkolnym. Wybrane problemy teoretyczne i praktyczne. Katowice: Wydawnictwo Uniwersytetu Śląskiego, 2007.

Klim-Klimaszewska, Anna, Wychowanie przedszkolne we wspótczesnym systemie oświaty na tle rysu historycznego. Warszawa: Polski Instytut Wydawniczy, 2005.

Landau, Zbigniew, Tomaszewski, Jerzy, „Spory o ocenę tendencji rozwoju gospodarki polskiej w latach 1918-1939", Przegląd Historyczny nr 75/4 (1984): 723-746. 
Landau, Zbigniew, Tomaszewski, Jerzy. Trudna niepodległość. Rozważania o gospodarce Polski 1918-1939. Warszawa: Wydawnictwo Książka i Wiedza, 1978.

Leżańska, Wiesława, „Wychowanie fizyczne w pedagogice Marii Weryho-Radziwiłłowiczowej. Początki gimnastyki w przedszkolach polskich. Journal of modern science 1 vol. 36 (2018): 11-26.

Mauersberg, Stanisław. „Sejm Nauczycielski (14-17 kwietnia 1919 r.)”. Rozprawy z Dziejów Oświaty 23 (1980): 139-156.

Moraczewska, Barbara. „Prekursorka instytucjonalnego wychowania małych dzieci w Polsce - Maria Weryho-Radziwiłłowiczowa (1858-1944)". Studia Gdańskie. Wizje i rzeczywistość 12 (2015): 215-231.

Ostrach, Zbigniew. „Rozwój praktyki przedszkolnej w ujęciu historycznym”. W: Praca przedszkola: wybrane zagadnienia teoretyczne, praktyczne i organizacyjne, red. Zbigniew Ostrach, 9-31. Kraków: Oficyna Wydawnicza Impuls, 2016.

Parchimowicz, Janusz, Borkowski, Tomasz. Katalog banknotów polskich i z Polskq zwiqzanych. Warszawa: Wydawnictwo Nefryt, 2001.

Samsel, Agata. „Wychowanie patriotyczne w przedszkolach II Rzeczypospolitej". W: Kobieta a patriotyzm. Konteksty historyczno-pedagogiczne XVI-XX wieku, red. Elwira. J. Kryńska, Artur Konopacki, Łukasz Kalisz, 121-136. Białystok: Wydawnictwo Trans Humana, 2012.

Samsel, Agata. „Wychowanie przedszkolne w latach 1918-1938 (cz. 2)”. Wychowanie w Przedszkolu 9 (2003): 518-522.

Samsel, Agata. „Wychowanie przedszkolne w latach 1918-1938 (cz. I)”. Wychowanie w Przedszkolu 8 (2003): 463-466.

Sandler, Bella. „Ochronki dziecięce Warszawskiego Towarzystwa Dobroczynności”. Rozprawy z Dziejów Oświaty 8 (1965): 103-132.

Sandler, Bella. „System Froebla w Galicji”. Rozprawy z Dziejów Oświaty 2 (1959): 199-223.

Sandler, Bella. Wychowanie przedszkolne i ksztatcenie wychowawczyń w Królestwie Polskim. Wrocław-Warszawa-Kraków: Zakład Narodowy im. Ossolińskich, 1968.

Sosnowska, Joanna. „Instytucje wychowania przedszkolnego w wielokulturowej Łodzi w latach 1924-1939. Organizacja, zadania, formy działania". Wychowanie w Rodzinie IX 1 (2014): 281-306.

Sosnowska, Joanna. „Wydawcy polskich czasopism pedagogicznych adresowanych do wychowawczyń przedszkoli i ich rola w popularyzowaniu idei 
wychowania przedszkolnego w II Rzeczypospolitej". W: Oświatowe i edukacyjne aspekty działalności wydawniczej $w$ XX wieku i pierwszych latach XXI wieku, red. Iwonna Michalska, Grzegorz Michalski, 6-28. Łódź: Wydawnictwo Uniwersytetu Łódzkiego, 2016.

Szewczuk, Dariusz. „Rola ochronek na Lubelszczyźnie w wychowaniu dzieci na przełomie XIX i XX wieku". W: Virginibus puerisque, t. 2: Z zagadnień wychowania i opieki nad dzieckiem $w$ XVIII-XX wieku, red. Ewa Kula, Marzena Pękowska, 173-184. Kielce: Wydawnictwo Uniwersytetu Jana Kochanowskiego w Kielcach, 2012.

Walasek, Stefania. „Ochronki i przedszkola w Wileńskim Okręgu Szkolnym w latach II RP". W: Wzrastać w cieniu historii: dzieci i młodzież $w$ instytucjach edukacyjnych $w$ Polsce (1918-1989), red. Elżbieta Gorloff, 49-64. Toruń: Wydawnictwo Adam Marszałek 2015.

Walasek, Stefania. „Przedszkola żydowskie na terenie lwowskiego i wileńskiego Kuratorium Okręgu Szkolnego w latach Drugiej Rzeczypospolitej”, Pedagogika Przedszkolna i Wczesnoszkolna 2 (4) (2014): 55-68.

Waloszek, Danuta. Historyczno-epistemologiczne podstawy pedagogiki przedszkolnej, Kraków: Wydawnictwo Naukowe Akademii Pedagogicznej, 2006.

Wałęga, Agnieszka. „Działalność opiekuńcza Pomorskiego Towarzystwa Opieki nad Dziećmi (1918-1948)". W: Virginibus puerisque, t. 2: Z zagadnień wychowania i opieki nad dzieckiem $w$ XVIII-XX wieku, red. Ewa Kula, Marzena Pękowska, 131-144. Kielce: Wydawnictwo Uniwersytetu Jana Kochanowskiego w Kielcach, 2012.

Wróbel, Maria, Wychowanie przedszkolne w Polsce w latach 1918-1939. Wrocław-Warszawa-Kraków: Zakład Narodowy im. Ossolińskich, 1967. 